\title{
The Canopy Structure and Its Impact on Hydrological Performance of Five Local Trees Species
} Grown in the Purwodadi Botanic Garden

Agung Sri Darmayanti*, Abban Putri Fiqa

\section{ABSTRACT}

The hydrological performance of individual tree can be estimated by measuring the stem flow, throughfall and rainfall interception. Water distribution through tree canopy is affected by tree architectural model and another tree's morphology. This research was done in order to predict the most appropriate tree species that is suitable on soil and water conservation. This research was conducted in Purwodadi Botanic Garden during the rainy season on January 2014 to March 2015, in order to examine the interception rate, throughfall and stemflow on some selected local plants i.e Syzygium polyanthum, Diospyros blancoi, Schleichera oleosa, Madhuca longifolia, and Canarium vulgare. Other observation that support the data, was also measured i.e. Leaf Area Index (LAI), crown depth, leaf size, Diameter of Breast Height (DBH), and height of tree on each species. Results showed that Diospyros blancoi has the highest interception value, which is $53 \%$, followed by C. vulgare 47.4\%, S. oleosa 46.9 $\%$, M. longifolia $38.6 \%$, and $S$. polyanthum $35.6 \%$ respectively. Under the heavy rain, D. blancoi, which has the highest LAI value, also showed the best performance in the rainfall interception value and showed significantly different among others. Canopy interception and stem flow is related to rainfall, the higher the rainfall, the higher the throughfall and the stemflow among species. Morphology on each species, gives the different effect on their partitioning rainfall value.

Keywords: Throughfall, stemfall, rainfall interception, local trees species, Purwodadi Botanic Garden

\section{INTRODUCTION}

Recycling hidrology is always spinning at any time, it is strongly influenced by the environment and greatly affect the environment. To better manage the hydrology elements, basic information on the environtment elements and inter-relating effects of them is essential. One of the hidrology elements is rainfall and one of the environtment elements is vegetation.The fall of rain water into the ground can be influenced with vegetation grown around area[1].

Interception is part of the rainfall that is intercepted by earth's surface includes everything that becomes wet after a rainfall event and that dries out soon after [2]. It is refers to precipitation that does not reach the soil, but is instead intercepted by leaves and branches of plants and the forest floor [3]. Interception can amount up to $15-50 \%$ of precipitation, which is a significant part of the water balance. The interception

*Corresponding author:

Agung Sri Darmayanti

Purwodadi Botanic Garden, Indonesian Institute of Sciences

Jalan Raya Surabaya Malang Km. 65, Pasuruan, Indonesia 67163

E-mail: yanthie82@gmail.com losses were dependent not only upon the intensity of rainfall events $[4,5]$ but also upon the size of the drops [6], and differences in interception losses among canopy species were explained by the size of throughfall drops [7]. Canopy interception can be calculated by measuring the hydrological performance of individual trees. It can be estimated by measuring stemflow, pass the crown gap (through-fall) and interception of rainwater [3].

Vegetation often modifies the intensity and distribution of rainfall by stem flow, through fall, and interception through its leaves and branch [8]. Besides rainfall and potential evaporation, interception also depends on the trees leaves ability to collect raindrops and prevent it fall down directly to the ground [9]. Tree architectural can describe those trees ability to conserve the soil surface. Their model is a tree building model as a result of plant growth controlled by meris-

How to cite:

Darmayanti AS, Fiqa AP (2016) The Canopy Structure and Its Impact on Hydrological Performance of Five Local Trees Species Grown in the Purwodadi Botanic Garden. J. Trop. Life. Science 7 (1): $40-47$. 
tematic morphogenetic. It is the shape and form of the trunk, how the branches are attached and arranged around the trunk, and the general outline of the crown, which includes the fine branches and foliages. The tree architectural models hadaffect to the amount of stem flow, through fall, and interception [10].

The shape of the leaves, the thickness, the density (Leaf Area Index) also can determine how much water can be stored. For example the capacity of a coniferous or a deciduous tree is different, deciduous tree can hold more water in its bucket-like leaves, a coniferous tree can hold much more water by adhesion[11].

A lot of research was conducted based on rainfall partition, e.g the species composition of vegetation cover and changes in land use affect the balance between throughfall, stemflow, interception and evapotranspiration $[12,13,14,15]$ These variables are modified by canopy cover, canopy architecture $[8,14$, $16,17,18]$. Leaf shape, orientation and size $[19,20]$, branch angle, leaf area index (LAI) and canopy gap fractions all play roles in rainfall partitioning $[18,21$, 22 ]. Stemflow is influenced by canopy volume and area [8], bark thickness, canopy architecture, and tree size and age $[21,23]$.

However, only few people study about local plants hydrological performance, in order to support their role to conserve water and soil. This research is important to support the utilization of local plant species to conserve and rehabilitate nature. The aim of this study was to evaluate the influence of plant canopy architecture model of the five plant to the rainfall factors, such as throughfall, stemflow, and interception in the Purwodadi Botanic Garden.

\section{MATERIALS AND METHODS}

Selected trees species are the local species Syzygium polyanthum, Diospyros blancoi, Schleichera oleosa, Madhuca longifolia, and Canarium vulgare. Those five species were chosen not only because of known as local trees but also reported as a potential on carbon sequestration [24].

The hydrological performance (through-fall, stem flow and rainfall interception) was measured for 20-30 rain events on each species. Rainfall was measured by locating an ombrometer at the open area. Throughfall was estimated by measuring the volume of rain water passes through the canopy each species that gathered in a plastic bucket. Stem flow was measured by using small water hose, wax, rubber tires and jerry cans. The water hose was cut to fit the trunk circumference and then mounted circularly at a height of about $1.3 \mathrm{~m}$.
The lower part of hose was tied with rubber installed to the jerry can to collect the rainwater flowing through the tree trunk, and this is the stem flow. Rainfall interception of the trees canopy was estimated using the formula [25]:

Interception, $\mathrm{mm}=$ Rainfall $-($ through-fall + stem flow $)$

The canopy characteristic that observed, they were height and width crown, leaf area, LAI, etc. Samples were 5 species local tree and were taken 2 replications of each species. The Leaf Area Index (LAI), measured by an LAI-2000 PlantCanopy Analyzer (LI-COR Inc., Lincoln, NE, USA) in 2000 changed from 3.9 to 5.2 with season [5] and the canopy was almost closed.Tree dimension that observed were tree height, crown height, crown diameter, and Diameter at Breast Height $(\mathrm{DBH})$. The other characters such as bark surface, leaf surface area, leaf width, and crown gap were directly measured after the experiment ended. At the end, all of the quantitative data was analyzed using MINITAB 14, to show the difference performance among species.

\section{RESULTS AND DISCUSSION}

During the research period, about 20-30 rainfall events were recorded. The hourly canopy interception showed a linear relationship with hourly rainfall in each rain event (Figure 1).The regression lines indicated that there is a relationship between rainfall and throughfall or rainfall and stemflow at each tree. The data for regression consist of pairs in the form $(x, y)$. The independent variable $(\mathrm{x})$ was rainfall. The dependent variable (y) is the effect that is observed during the experiment, they are interception, throughfall, or stemflow. The equation $\mathrm{y}=\mathrm{mx}+\mathrm{b}$, where $\mathrm{m}$ is the slope of the line, and $b$ is the $y$-intercept of the line. From this result of study, the slope of the regression line is positive (the value of $y$ increases as the value of $\mathrm{x}$ increases). This is called a positive correlation.

Throughfall was found to be closely related to rainfall, the higher rainfall, the higher throughfall were measured. A very strong positive linear relationship was observed in S. polyanthum, D. blancoi, S. oleosa, and $M$. longifolia (R2 > 0.9). Stemflow was correlated to rainfall intensity and showed clearly in M. longifolia and D. blancoi, whereas other species are not (Figure 2 ). The strong positive relationship between interception and rainfall was observed only in $M$. longifolia $(\mathrm{R} 2>9)$. All of species showed that the increasing of rainfall caused the increasing of interception percentage. 


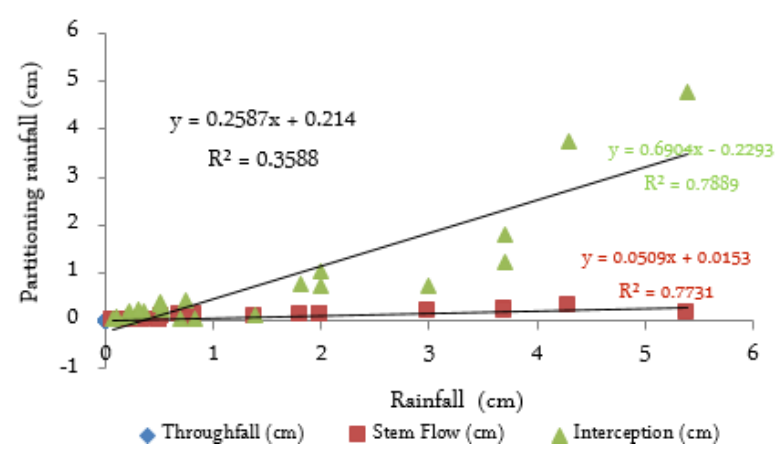

(a)

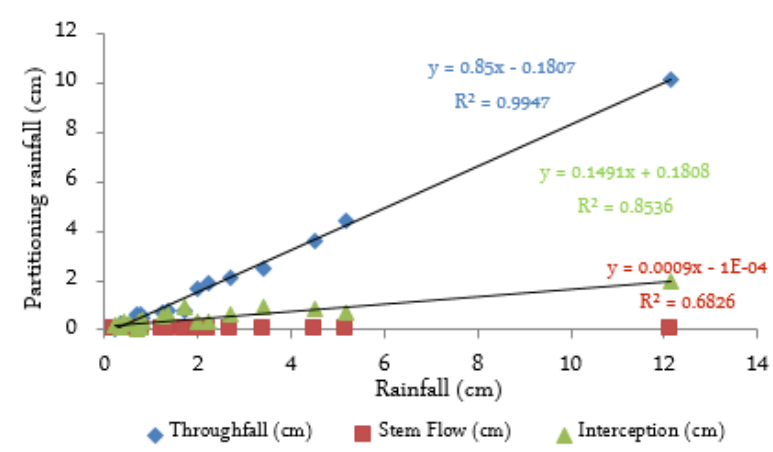

(c)

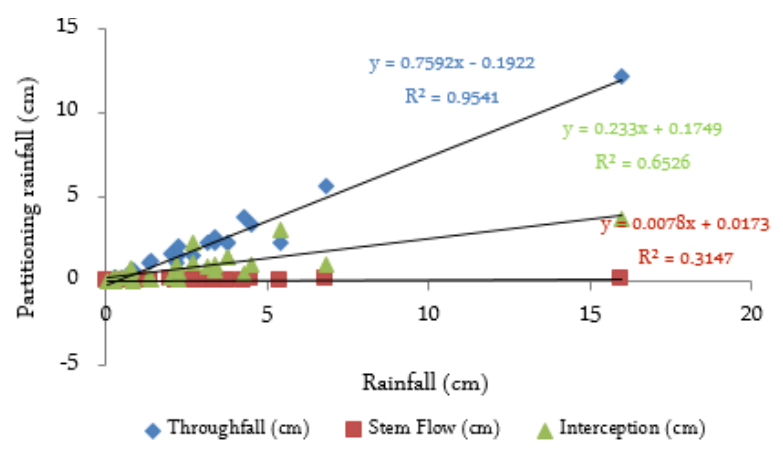

(b)

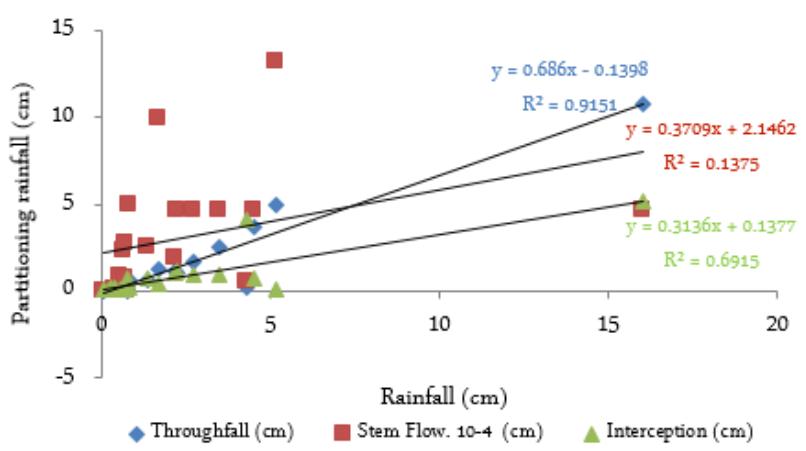

(d)

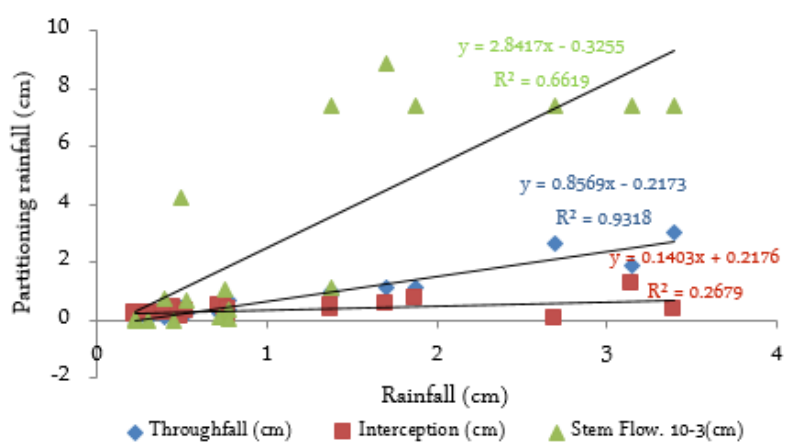

(e)

Figure 1. The Relationship between Rainfall Average and partitioning rainfal (Canopy Interception, Through Fall and Stem Flow) Patterns on (a) D. blancoi, (b) S. polyanthum, (c) M. longifolia (d) S. oleosa, and (e) C. vulgare

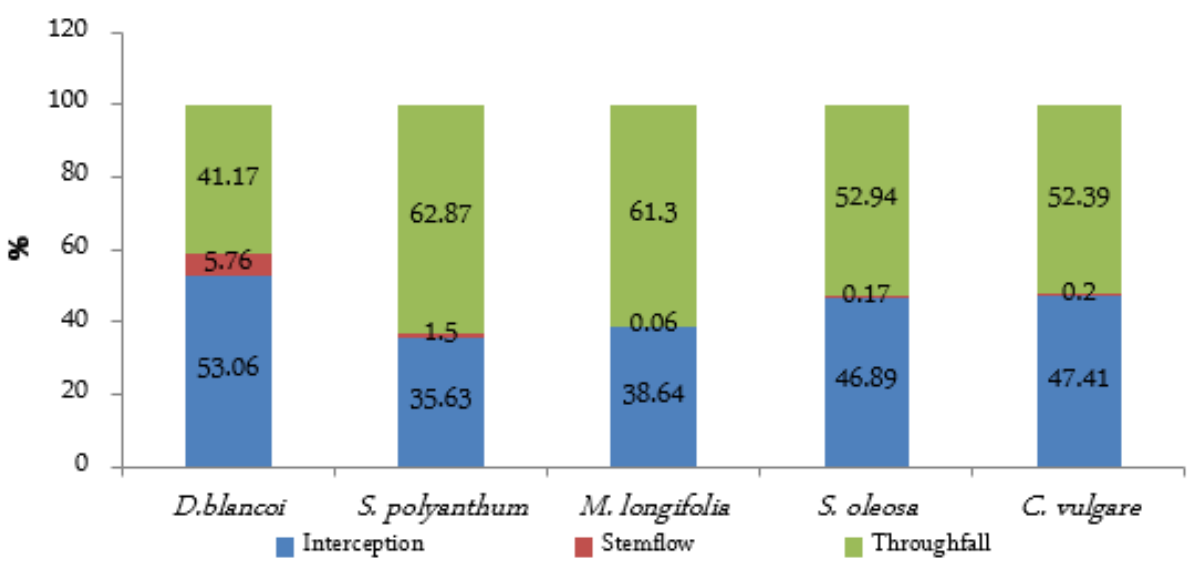

Figure 2. Throughfall, stemflow, and interception (\%) of five selected plants 
Results showed that $D$. blancoi has the highest interception value, which is $53 \%$, followed by $C$. vulgare $47.4 \%$, S. oleosa $46.9 \%$, M. longifolia $38.6 \%$, and $S$. polyanthum $35.6 \%$ respectively (Figure 2 ). Rainfall was divided into two categories to see the differences how much rainfall work on the hydrological performance among five species selected. Rainfall was classified into 2 classes: rainfall $<3 \mathrm{~cm}$ and $>3 \mathrm{~cm}$. Table 1 shows stemflow, throughfall, and interception in each species on heavy and light rain.

The interception rate, capacity and losses depend on many factors including vegetation characteristics and meteorological factors. Vegetation characteristics factors may consist of growth form, plant structure plant density and plant community structure. Meteorological factors may consist of precipitation intensity, precipitation duration, winds speed, type of rainfall and precipitation frequency [26].

Table 2 showed the character, including LAI, dbh, and other quantitative character to showed how difference are one species compared others. C. vulgare is a large tree, it has big stem diameter, width and tight canopy. It can be observed in the results of its measurements are $210 \mathrm{~cm} \mathrm{DBH;} 26.914 \mathrm{~m}$ crown height; $37.167 \mathrm{~m}$ tree height; $7,395,838 \mathrm{~cm}^{2}$ crown area. D. blancoi that was observed in this study had value of $\mathrm{DBH}$, crown height, tree height, and crown area smallest, but highest of LAI.

The detail trees character is shown in Table 3, describe the descriptive character that may affect trees performance in its hydrological role. Five species observed, showed interception values that relatively high. Interception is considered to be about 15 to $50 \%$ of the total incoming precipitation on forests in temperate humid latitudes [27, 28, 29]. Breuer et al. find that some of these results were summarized, which show that 30$40 \%$ of the rainfall can evaporate through interception.

High interception value may support the soil conservation, since leaves tree can prevent a rainfall drop directly to the soil surface, that might damage soil macro and microporosity and inhibit water infiltration, while stem flow may support the water infiltration to the soil. The redirection of water by this process causes surface soil become moist. Otherwise, througfall may cause the leak of soil porusity. These drops have an erosive power because it is larger than rain drops, however, if the height of canopy was shorter, their erosive power is reduced. In the case of a high canopy, canopy height requirement for the drops to reach terminal velocity is about 8 metres, than the erosive power will in- creased [31].

The statistical results showed that $D$. blancoi performing the highest value of interception percentage and significantly different among the other species under the heavy rains. Although $D$. blancoi has low crown height and narrow crown diameter, it has the highest LAI that support its interception percentage. LAI is a dimensionless quantity that characterizes plant canopies. It is defined as the one-sided green leaf area per unit ground surface area LAI (area/ground area, $\mathrm{m}^{2} / \mathrm{m}^{2}$ ) in broad leaf canopies [32]. The leaf of $D$. blancoi is wide and has a glabrous surface (Table 2) so it can retain water drop to the soil. The amount of stemflow is determined by leaf shape and stem and branch architecture [33]. Others studies show that there is a large difference in the canopy interception by deciduous and coniferous trees $[9,11,30]$ because the leaf area of coniferous trees is much larger than of deciduous trees, coniferous trees can store much more water.

It is reported that stemflow quantity is affected by the bark roughness [34]. D. blancoi has a rough bark, so it should be gathered less stemflow than smooth bark, but the research showed the opposite result. Either on the hard rain or in the light rain, D. blancoi performs the highest stemflow and significantly difference among the other species. $D$. blancoi has a tight canopy gap, this character supporting the rainfall concentrated in the leaves then flows to the main stem. In any case, not only bark roughness might give an impact to the stemflow, leaf shape and orientation or branch angle also give contribution or even may have negated the bark roughness effect $[18,35]$. At branch inclinations of $60^{\circ}$ above the horizontal, the quantity of branch flow was found to be $>80 \%$ of the total quantity of impacting rainfall [36].

Heavy rain may give a different affect compare with the light rain. It is shown in the Table 2, D. blancoi has the highest stemflow compare with other species. Heavy rain may caused the water drop irregular. The rainfall intensity is important, [37] concluded that the interception capacity is lower at higher intensity because high rainfall intensities cause splashing and shaking of leaves. On the other hand, [38] found the opposite: high rainfall intensities coincide with high storage capacities, due to dynamic storage

Massart model of $D$. blancoi with monopodium main stem and ortothropic, the main branch is plagiothropic, rhythmic growth resulted branches arranged in a bouquet [38] make D. blancoi has high stemflow and interception. Large canopy diameter of S. polyan- 
Table 1. Summary of throughfall, stemflow and interception for five tropical tree species based on the rainfall intensity

\begin{tabular}{llllll}
\hline & D. blancoi & S. polyanthum & S.oleosa & M. longifolia & C.vulgare \\
\hline Heavy Rain & & & & & \\
Rainfall $(\mathrm{cm})$ & $>3$ & $>3$ & $>3$ & $>3$ & $>3$ \\
Stemflow $(\mathrm{cm})$ & $0.22(\mathrm{a})$ & $0.07(\mathrm{~b})$ & $0.01(\mathrm{c})$ & $0.01(\mathrm{c})$ & $0.01(\mathrm{c})$ \\
Throughfall $(\mathrm{cm})$ & $1.48(\mathrm{a})$ & $4.28(\mathrm{ab})$ & $5.17(\mathrm{~b})$ & $4.15(\mathrm{ab})$ & $2.46(\mathrm{ab})$ \\
Interception $(\mathrm{cm})$ & $2.55(\mathrm{a})$ & $1.47(\mathrm{bc})$ & $1.13(\mathrm{c})$ & $2.22(\mathrm{~b})$ & $0.81(\mathrm{c})$ \\
\hline Light Rain & & & & & \\
Rainfall $(\mathrm{cm})$ & $<3$ & $<3$ & $<3$ & $<3$ & $<3$ \\
Stemflow $(\mathrm{cm})$ & $0.05(\mathrm{a})$ & $0.025(\mathrm{~b})$ & $0.00(\mathrm{c})$ & $0.00(\mathrm{c})$ & $0.00(\mathrm{c})$ \\
Throughfall $(\mathrm{cm})$ & $0.49(\mathrm{a})$ & $0.69(\mathrm{a})$ & $0.39(\mathrm{a})$ & $0.55(\mathrm{a})$ & $0.57(\mathrm{a})$ \\
Interception $(\mathrm{cm})$ & $0.29(\mathrm{a})$ & $0.45(\mathrm{a})$ & $0.32(\mathrm{a})$ & $0.45(\mathrm{a})$ & $0.34(\mathrm{a})$ \\
\hline
\end{tabular}

Note: - Means followed by different letters are significantly different (least significant difference (LSD) $\mathrm{p} \leq 0.05$ )

- *Stemflow and throughfall were calculated on between 20 and 30 rain events.

$-{ }^{* *}$ Interception was calculated only for rain events in which both throughfall and stemflow was occurred.

Table 2. Character of D. blancoi, S. polyanthum, M.longifolia, S. oleosa, and C. vulgare

\begin{tabular}{|c|c|c|c|c|c|c|}
\hline & Species & D.blancoi & S.polyanthum & S. oleosa & M. longifolia & C. vulgare \\
\hline & $\mathrm{DBH}(\mathrm{cm})$ & $72.00(\mathrm{a})$ & $145.00(\mathrm{~b})$ & $123.00(a b)$ & $127.50(\mathrm{ab})$ & $210.00(\mathrm{c})$ \\
\hline & Crown height $(\mathrm{m})$ & $6.90(\mathrm{a})$ & $21.86(\mathrm{bc})$ & $20.82(b c)$ & $18.34(b)$ & $26.91(c)$ \\
\hline Vegetation & Height (m) & $9.80(\mathrm{a})$ & $27.80(\mathrm{bc})$ & $25.31(\mathrm{bc})$ & $24.28(\mathrm{c})$ & $37.17(b)$ \\
\hline \multirow[t]{3}{*}{ Characteristics } & LAI & $3.04(\mathrm{a})$ & $2.17(b)$ & $2.63(\mathrm{ab})$ & $2.50(\mathrm{ab})$ & $2.7(\mathrm{ab})$ \\
\hline & leaf area $\left(\mathrm{cm}^{2}\right)$ & $138.80(\mathrm{a})$ & $59.93(\mathrm{bc})$ & $42.30(b)$ & $36.40(\mathrm{~b})$ & $97.59(\mathrm{c})$ \\
\hline & Crown area $\left(\mathrm{cm}^{2}\right)$ & $150,000(a)$ & $799,850(a)$ & $1,142,687(\mathrm{ab})$ & $4,322,406(b)$ & $7,395,838(b)$ \\
\hline
\end{tabular}

Note: Means followed by different letters are significantly different (least significant difference (LSD)p $\leq 0.05$ )

Table 3. Morphology tree forming their architecture

\begin{tabular}{|c|c|c|c|c|c|}
\hline Species & Family & Leaves & Crown Gap & Stems and Brances & Architecture \\
\hline $\begin{array}{l}\text { Diospyros blancoi } \\
\text { A.DC }\end{array}$ & Ebenaceae & Alternate, oblong, glabrous & Tight & $\begin{array}{l}\text { Single stem, monopodial, } \\
\text { plagiotropic branches, rough }\end{array}$ & Massart \\
\hline $\begin{array}{l}\text { Syzygium polyanthum } \\
\text { (Wight) Walp. }\end{array}$ & Myrtaceae & $\begin{array}{l}\text { Elliptical-ovate, Leafleats 6-10, } \\
\text { petiole 5- } 12 \mathrm{~mm}\end{array}$ & Large & $\begin{array}{l}\text { Single stem, sympodial, } \\
\text { plagiotropic branches, rough }\end{array}$ & Champagnat \\
\hline $\begin{array}{l}\text { Schleichera oleosa } \\
\text { (Lour.) Merr. }\end{array}$ & Sapindaceae & $\begin{array}{l}\text { Leaves paripinnate, alternate, } \\
\text { leaflets 4-6; glabrous, elliptic- } \\
\text { oblong, ovate or obovate, }\end{array}$ & Large & $\begin{array}{l}\text { Single stem, monopodial, } \\
\text { surface grey, smooth, brittle }\end{array}$ & Scarone \\
\hline $\begin{array}{l}\text { Madhuca longifolia ( } \\
\text { J.König ex L.) }\end{array}$ & Sapotaceae & $\begin{array}{l}\text { Palmately compound., } \\
\text { oblancealate-lanceolate, leafleat } \\
4-7\end{array}$ & Large & $\begin{array}{l}\text { Single stem, monopodial, } \\
\text { continous, ortotropic } \\
\text { branches, surface grey, rough } \\
\text { enough }\end{array}$ & Troll \\
\hline $\begin{array}{l}\text { Canarium vulgare } \\
\text { Leenh. }\end{array}$ & Burceraceae & $\begin{array}{l}\text { Pinnatelly Compound. Spirally } \\
\text { arranged, glabrous, elliptic } \\
\text { oblong. Leafleat } 6-8\end{array}$ & Medium & $\begin{array}{l}\text { Single stem, monopodial, } \\
\text { Ritmik, Ortotrophic branches, } \\
\text { surface grey, smooth }\end{array}$ & Rauh \\
\hline
\end{tabular}

thum and its medium elliptical-ovate leaves and also its rough bark textures sothat the stemflow capacity was higher than M. longifolia, S. oleosa, and C. vulgare. $S$. polyanthum with its Champagnat architecture and round canopy shape (Figure 3), also support the rain water converge to its main stem. Rough and scaly bark texture will increase the interception capacity because it retains the water flowing through the trunk and stem 


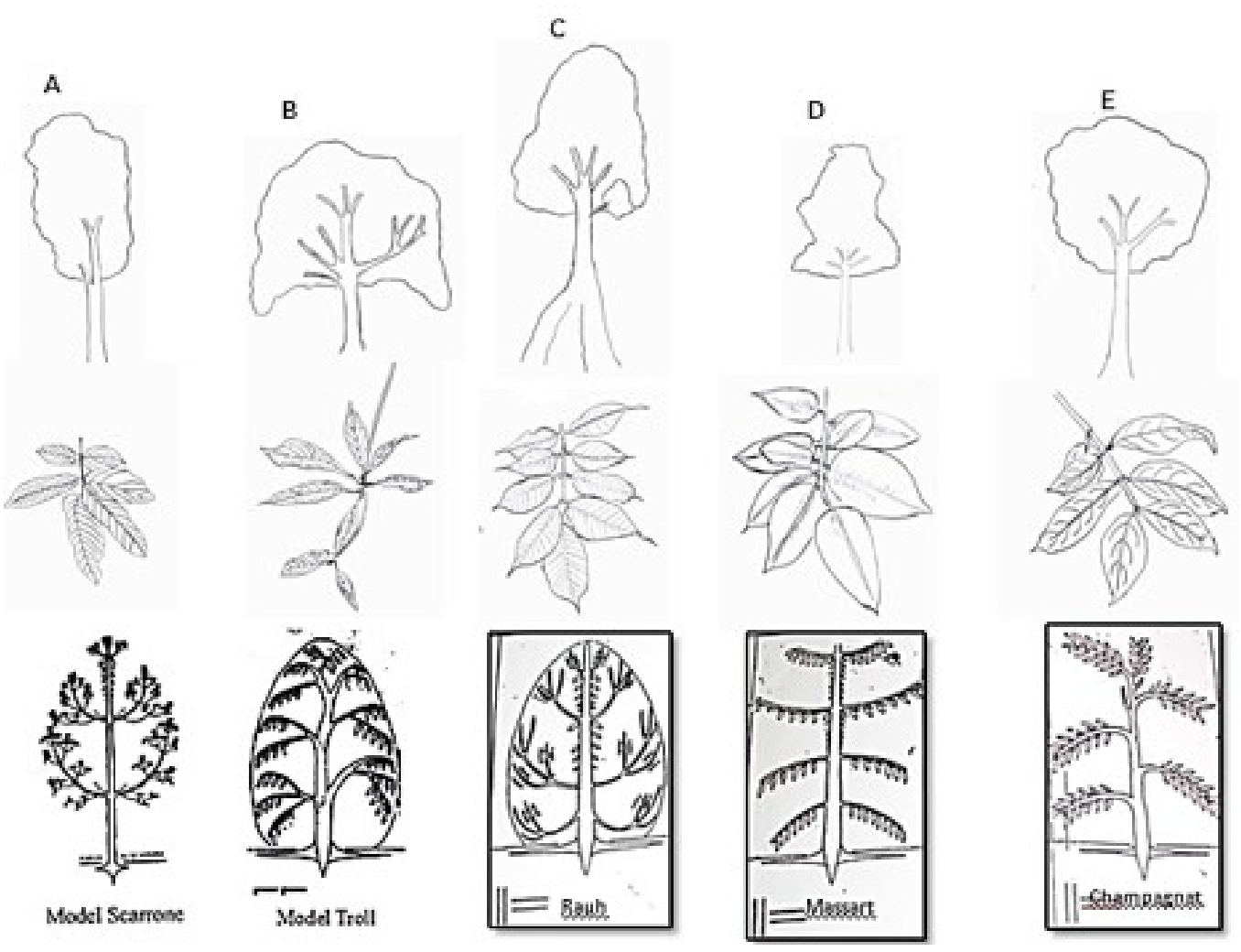

Figure 3. Basic tree architecture, morphology and leaf characteristics of tree species: (A) S. oleosa, (B) M. longifolia, (C) C. vulgare, (D) D. blancoi and (E) S. polyanthum. Trees and leaves are drawn approximately to scale relative to each other (Drawing by Abban Putri Fiqa)

[37]. In heavy rain, was seen significant different among the species. Stemflow was lowest and throughfall was highest in $S$. oleosa, was caused of its rough bark and its wide canopy gap. It has small leaves and downwards oriented, cannot continue the rain water into the stem, but loss as the throughfall. This condition also happen in the $M$. longifolia which has the dangled down canopy types (Figure 3). This canopy type made most of the rain drop received by the leaves will be loss as a throughfall. Troll model at M. longifolia have plagiothropic patterns in all of axis, then into upright because a secunder growth or there is a bending process [10]. Rauh model at $C$. vulgare has monopodium ortothropic branching and a rhytmic growth cause the low of stemflow and interception [40].

\section{CONCLUSION}

Diospyros blancoi has the highest interception value, which is $53 \%$, followed by $C$. vulgare $47.4 \%$, S. oleosa $46.9 \%$, M. longifolia $38.6 \%$, and S. polyanthum $35.6 \%$ respectively. The highest interception value support soil conservation, but combination of vegetation in the land use is especially important. Combination characteristics of tree can reduce energy of water to hit the soil so can prevent soil destruction. Stemflow, throughfall, and interception were correlated with rainfall. Stemflow, througfall, and interception increased with higher rainfall, while LAI, crown depth, leaf size, dense canopy supported the high interception.

\section{ACKNOWLEDGMENT}

\section{REFERENCES}

1. Zhang GH, Liu GB, Wang GL, Wang YX (2011) Effects of vegetation cover and rainfall intensity on sediment-associated nitrogen and phosphorus losses and particle size composition on the Loess Plateau. Journal of Soil and Water Conservation 66 (3): 192-200. doi:10.1016/S10020160(11)60170-7.

2. Gerrits $A M J$ and Savenije HHG. Interception. In: Wilderer P (ed.) (2011) Treatise on Water Science, Vol. 2. Oxford, Academic Press.

3. Gerrits AMJ (2010) The role of interception in the hydro- 
logical cycle. PhD thesis. Delft University of Technology, Water Resources Department.

4. Crockford RH, Richardson DP (2000) Partitioning of rainfall into throughfall, stemflow and interception: effect of forest type, ground cover and climate. Hydrology Process 14 (16-17): 2903-2920. doi:10.1002/1099-1085(2 00011/12)14:16/17<2903::AID-HYP126>3.0.CO;2-6

5. Murakami S (2006) A proposal for a new forest canopy interception mechanism: Splash droplet evaporation. Journal of Hydrology 319: 72-82. doi:10.1016/j.jhydrol.2005.07. 002

6. Calder IR, (1996) Dependence of rainfall interception on drop size1. Further development of the stochastic model. Journal of Hydrology 185: 363-378.

7. Hall LR (2003) Interception loss as a function of rainfall and forest types: Stochastic modeling for tropical canopies revised. Journal of Hydrology 280: 1-12. Doi: 10.1016/S0022-1694(03)00076-3

8. Darmayanti AS dan Solikin (2013) Infiltrasi dan Limpasan Permukaan pada Pola Tanam Agroforestri dan Monokultur: Studi di Desa Jeru Kabupaten Malang. Prosiding Seminar Nasional X (Biologi, Sains, Lingkungan, dan Pembelajarannya) 6 July 2013; Surakarta. Edited by: Rinanto Y et.al. Fakultas Keguruan dan Ilmu Pendidikan, Pendidikan Biologi, Universitas Sebelas Maret. 18-190.

9. Bryant ML, Bhat S, Jacobs JM (2005) Measurements and modeling of throughfall variability for five forest communities in the southeastern US. Journal of Hydrology 312:95-108. Doi.org/10.1016/j.jhydrol.2005.02.012.

10. Halle F, Oldeman RAA, Tomlinson PB (1978) Tropical Trees and Forests: An Architectural Analysis. New York, Springer-Verlag.

11. Toba T, Ohta $T$ (2005) An observational study of the factors that influence interception loss in boreal and temperate forests. Journal of Hydrology 313:208-220. doi: 10.1016/j.jhydrol.2005.03.003.

12. Herbst M, Rosier PT, McNeil DD et al. (2008) Seasonal variability of interception evaporation from the canopy of a mixed deciduous forest. Agricultural and Forest Meteorology 148 (11): 1655-1667. doi: 10.1016/j.agrformet.2008. 05.011

13. Bruijnzeel LA (2000) The Forests Handbook, Vol 1. Oxford, Blackwell Scientific.

14. Budiastuti S (2006) Pohon dan sistem agroforestri dalam area resapan air: peran tajuk dan strata tajuk sebagai pengendali sistem hidrologi. Master Tesis. Universitas Brawijaya, Fakultas Pertanian.

15. Jian S, Zhao C, Fanga S, Yu K (2015) Effects of different vegetation restoration on soil water storage and water balance in the Chinese Loess Plateau. Agricultural and Forest Meteorology 206: 85-96. doi: 10.1016/j.agrformet.2015.03.
009.

16. Huber A, Iroume Â (2001) Variability of annual rainfall partitioning for different sites and forest covers in Chile. Journal of Hydrology 248:78-92. doi: 10.1016/S00221694(01)00394-8.

17. Pypker TG, Bond BJ, Link TE et al. (2005) The importance of canopy structure in controlling the interception loss of rainfall: Examples from a young and an old-growth Douglas-fir forest. Agricultural and Forest Meteorology 130: 113-129. doi: 10.1016/j.agrformet.2005.03.003.

18. Park A, Cameron JL (2008) The influence of canopy traits on throughfall and stemflow in five tropical trees growing in a Panamanian plantation. Forest Ecology and Management 255: 1915-192. doi: 10.1016/j.foreco.2007.12.025

19. Calder IR (2001) Canopy processes: Implications for transpiration, interception and splash induced erosion, ultimately for forest management and water resources. Plant Ecology 153 (1): 203-214. Doi:10.1023/A:1017580311070

20. Nanko K, Hotta N, Suzuki M (2006) Evaluating the influence of canopy species and meterological factors on throughfall drop size distribution. Journal of Hydrology. 329: 422-43. doi:10.1016/j.jhydrol.2006.02.036

21. Levia DF, Herwitz SR (2005) Interspecific variation of bark water storage capacity of three deciduous tree species in relation to stemflow yield and solute flux to forest soils. Catena 64: 117- 137. doi: 10.1016/j.catena.2005.08.001

22. Johnson MS, Lehmann J (2006) Double-funneling of trees: Stemflow androot-induced preferential flow. Ecoscience 13: 324-333.

23. Levia DF and Frost EE (2003) A review and evaluation of stemflow literature in the hydrologic and biogeochemical cycles of forested and agricultural ecosystems. Journal of Hydrology 274: 1-29. doi: 10.1016/S0022-1694(02)003992.

24. Yulistyarini T, Danarto SA, Purwodadi Botanic Garden local plants collection and their potency as carbon sink. Unpublished.

25. Ahmed A, Tomar JMS, Mehta $\mathrm{H}$ et al. (2015) Influence of canopy architecture on stemflow inagroforestry trees in Western Himalayas. Current Science 109 (4): 759-764.

26. Kuchment LS (2004) The hydrological cycle and human impact on it, in Arjen Y, Hoekstra, and Savenije HHG (2004) in Encyclopedia of Life Support Systems (EOLSS), Developed under the Auspices of the UNESCO, Eolss Publisherd, Oxford, UK. http://www.eolss.net. Accessed: November 2015.

27. Viville D, Biron P, Granier A et al. (1993) Interception in a mountainous declining spruce stand in the Stengbach catchment (Vosges, France). Journal of Hydrology 144: 273-282. doi: 10.1016/0022-1694(93)90175-9

28. Hormann G, Branding A, Clemen T et al. (1996) Calcula- 
tion and simulation of wind controlled canopy interception of a beech forest in Northern Germany. Agricultural and Forest Meteorology 79 (3): 131-148. doi: 10.1016/0168-1923(95)02275-9.

29. Savenije HHG (2004) The importance of interception and why we should delete the term evapotranspiration from our vocabulary. Hydrological Processes 18 (8): 1507-1511. doi: 10.1002/hyp.5563.

30. Breuer L, Eckhardt K, Frede HG (2003) Plant parameter values for models in temperate climates. Ecological Modelling 169 (2-3): 237 - 293. doi: 10.1016/S03043800(03)00274-6.

31. Stuart GW, Edwards PJ (2006) Concepts about Forests and Water. Northern Journal of Applied Forestry 23 (1): $11-19$.

32. Watson DJ (1947) Comparative physiological studies on the growth of field crops: I. Variation in net assimilation rate and leaf area between species and varieties and within and between years. Annals of Botany 11: 41-76.

33. Petersen J, Dorothy S, Gabler RE (2015) Fundamentals of physical geography (2nd Edition) http://www.physicalgeography.net/. Accessed: November 2015.

34. Johnson RC (1990) The interception, throughfall and stemflow in a forest in highland Scotland and the comparison with other upland forests in UK. Journal of Hydrologic 118: 281-287. doi: 10.1016/0022-1694(90)90263-W

35. Darmayanti AS, Hapsari L (2011) The hydrological aspects on some selected local plants; Flamboyan (Delonix regia), Sawo (Manilkara achras), Dau (Dracontomelon dao) and Bintaro (Cerbera manghas) and its potential role for land and water conservation. Proceeding of the International Conference on Mathematics and Sciences (ICOMSc) Part 1 Statistics Biology. 12-13 October 201; Surabaya. Edited by: Santoso M. Fakultas MIPA, Institut Teknologi Sepuluh November. P07-10.

36. Herwitz SR (1987) Raindrop impact and water flow on the vegetative surfaces of trees and the effects on stemflow and throughfall generation. Earth Surface Processes and Landforms 12 (4): 425-432. doi: 10.1002/esp.3290120408.

37. Wang A, Diao Y, Pei T et al. (2007) A semi-theoretical model of canopy rainfall interception for a broad-leaved tree. Hydrological Processes 21 (18): 2458-2463. doi: 10.1002/hyp.6413.

38. Valova M, Bieleszova S (2008) Interspecific variations of bark's water storage capacity of chosen types of trees and the dependence on occurrence of epiphytic mosses. GeoScience Engineering 54: 45-51.

39. Hasanuddin (2013) Model Arsitektur Pohon Hutan Kota Banda Aceh Sebagai Penunjang Praktikum Morfologi Tumbuhan. Jurnal EduBio Tropika 1 (1): 38-44.

40. Utami MS (2012) Korelasi arsitektur pohon model rauh dari Rasamala (Altingia excelsa Noronha.) dan model arsitektur Roux dari jenis kopi (Coffea arabica L.) terhadap konservasi tanah dan air di area PHBM RPH Gambung Kph Bandung Selatan. Master Thesis. Institut Pertanian Bogor, Fakultas MIPA. 